\title{
EFEK TEKNOLOGI LUCUTAN PLASMA PADA ORGANOLEPTIK DAGING IKAN NILA (OREOCHROMIS NILOTICUS)
}

\author{
Yunus Susilo"1, Achmad Rifandi Satria Aji ${ }^{2}$, Akhmad Taufik Mukti ${ }^{3}$ \\ ${ }^{1}$ Fakultas Teknik, Universitas Dr. Soetomo, Surabaya-Indonesia 60119 \\ ${ }^{2}$ Departemen Fisika, Fakultas Sains dan Teknologi-Universitas Airlangga, Surabaya- \\ Indonesia 60115 \\ ${ }^{3}$ Departemen Manajemen Kesehatan Ikan dan Akuakultur, Fakultas Perikanan dan Kelautan- \\ Universitas Airlangga, Surabaya-Indonesia 60115
}

e-mail: *1yunus.susilo@ unitomo.ac.id, achmad.rifandhi.satria-2016@ fst.unair.ac.id, akhmad-tm@fpk.unair.ac.id

\begin{abstract}
Abstrak
Penelitian ini bertujuan untuk mengetahui efektivitas ozon dalam menghambat kerusakan pada ikan nila (Oreochromis niloticus). Penelitian ini dilakukan dengan memberikan pemaparan ozon pada ikan nila (Oreochromis niloticus) dengan teknik pemaparan ozon melalui air dengan variasi waktu alir, yaitu 0 detik, 540 detik, 360 detik, dan 180 detik. Sampel ikan nila (Oreochromis niloticus) diperoleh dari tempat budidaya ikan nila di Tanggulangin, Kota Sidoarjo. Penelitian ini dilakukan dengan teknik Rancangan Acak Lengkap (RAL). Pengamatan dilakukan setiap 12 jam sekali selama 48 jam atau 2 hari berupa pengujian organoleptik pada ikan nila (Oreochromis niloticus). Hasil uji organoleptik menunjukkan bahwa teknik paparan ozon melalui air dengan waktu alir 3 menit dalam waktu penyimpanannya selama 12 jam dengan konsentrasi ozon 0,0203 $\mathrm{mg} / \mathrm{L}$ memberikan hasil yang terbaik dalam menghambat kerusakan mutu kualitas ikan nila (Oreochromis niloticus) yang ditandai dengan perubahan pada mata, insang, lendir permukaan badan, daging, bau, dan tekstur ikan nila (Oreochromis niloticus) serta spesifikasi pada ikan yang paling efektif dalam menghambat kerusakan adalah pada penampakan lendir permukaan badan dan bau pada ikan nila (Oreochromis niloticus).
\end{abstract}

Kata kunci-ikan nila (Oreochromis niloticus), ozon, organoleptik

This study aims to determine the effectiveness of ozone in inhibiting damage to tilapia (Oreochromis niloticus). This research was conducted by providing ozone exposure to tilapia (Oreochromis niloticus) with ozone exposure techniques through water with variations in flow time, namely 0 seconds, 540 seconds, 360 seconds, and 180 seconds. Tilapia (Oreochromis niloticus) samples were obtained from tilapia fish farming in Tanggulangin, Sidoarjo City. This research was conducted using a completely randomized design (CRD) technique. Observations were carried out every 12 hours for 48 hours or 2 days in the form of organoleptic testing on tilapia (Oreochromis niloticus). Organoleptic test results showed that the technique of exposure to ozone through water with a flow time of 3 minutes in storage time for 12 hours with an ozone concentration of $0.0203 \mathrm{mg} / \mathrm{L}$ gave the best results in inhibiting the quality deterioration of tilapia (Oreochromis niloticus) which was characterized by 
changes in The eyes, gills, body surface mucus, meat, smell, and texture of tilapia (Oreochromis niloticus) and the specifications for the fish that are most effective in inhibiting damage are the appearance of body surface mucus and odor in tilapia (Oreochromis niloticus).

Keywords - tilapia (Oreochromis niloticus), ozone, organoleptic 


\section{PENDAHULUAN}

Ikan merupakan satu diantara sumber bahan hewani yang memiliki kandungan protein, lemak, karbohidrat, vitamin dan mineral serta dari kandungan tersebut yang paling besar adalah terdapat pada protein. Menurut (Irawan, 1997) mengatakan bahwa protein merupakan unsur terbesar setelah air. Kandungan pada protein sekitar $24 \%$ dan pada air sekitar $76 \%$ merupakan satu diantara media yang cocok untuk kehidupan bakteri pembusuk atau mikroorganisme lain, sehingga ikan tersebut sangat cepat mengalami proses pembusukan. Pembusukan pada ikan ini disebabkan karena kandungan air pada daging ikan sangat tinggi dan menyebabkan ikan tersebut menjadi media yang cocok untuk kehidupan bakteri dan mikroorganisme lain sehingga pembusukan tersebut lebih cepat dibandingkan daging ternak atau hewan lain dan mutu ikan berkurang serta tidak layak dikonsumsi (Gustini, 2014).

Oleh karena itu, mutu pada kualitas daging ikan dapat dipertahankan apabila ikan tersebut ditangani dengan hati-hati (carefull), bersih (clean), disimpan dalam ruangan dengan suhu yang dingin (cold), dan cepat (quick) (Wibowo, 2014). Mutu pada kualitas daging ikan ini perlu dideteksi adanya kesegaran daging ikan. Hal ini dikarenakan untuk mengurangi kualitas daging ikan yang mengalami pembusukan sehingga kandungan gizi pada daging ikan ini tetap terjaga. Adapun upaya yang dilakukan untuk mengatasi terjadinya pembusukan pada ikan adalah dengan melalui pendinginan. Pendinginan merupakan satu diantara cara yang dilakukan untuk mengatasi terjadinya pembusukan pada ikan. Pendinginan ini biasanya menggunakan es dan pada umumnya ikan ini ditujukan ke pasar ikan yang masih dalam keadaan basah dengan menurunkan suhu atau temperatur pada daging ikan dari $-1{ }^{\circ \mathrm{C}}$ ' sampai dengan $2^{\circ C}$. Tujuan dari penambahan es pada daging ikan adalah agar dapat mempertahankan ikan tetap segar serta mencegah pembusukan sehingga nilai gizi pada ikan tetap terjaga walaupun tidak terlalu lama. Untuk mengetahui adanya mutu kualitas pada daging ikan adalah dengan menggunakan ozon (ozone).
Ozon (ozone) merupakan suatu gas yang terbentuk dari tiga atom oksigen $\left(\mathrm{O}_{3}\right)$ yang bersifat sangat reaktif dan lebih tidak stabil dibandingkan dengan oksigen dan ozon tersebut terbentuk dari pengoksidasi yang kuat dengan kekuatan oksidasi enam kali dari oksidasi klorin (Astuti, dkk, 2019; Astuti dkk, 2020; Putri, 2020). Ozon (ozone) termasuk gas yang tak berwama dengan bau yang khas sehingga dapat terdeteksi oleh indera cium sampai dengan konsentrasi $0,01 \mathrm{ppm}$ (part per million). Oleh karena itu, konsentrasi pada gas ozon dengan ruang terbuka maksimum sekitar $0,10 \mathrm{ppm}$, sedangkan konsentrasi tertinggi sekitar $1,00 \mathrm{ppm}$ yang masih dapat dikategorikan tak berbahaya. Selain itu, sifat yang terpenting dari ozon adalah mampu menyerap radiasi tenaga tinggi dengan panjang gelombangnya antara 220360 nanometer $(\mathrm{nm})$ yang merupakan daerah spektrum ultraviolet (UV) (Purwadi, 2003).

Gas ozon tersebut berfungsi sebagai sterilisasi pada bahan terutama pada kualitas daging ikan yang akan diteliti. Selain untuk sterilisasi pada kualitas kesegaran daging ikan, ozon juga

berfungsi sebagai desifektan untuk membunuh virus dan mikroorganisme dan meningkatkan suplemen dalam air yang mana hasil akhir reaksinya dapat berupa oksigen (O2) (Prasetyo, 2015).

Pada penelitian ini sangat penting karena untuk mengetahui kualitas pada ikan bersisik baik melalui pengawetan menggunakan es batu maupun tanpa menggunakan es batu. Hal ini dapat teramati dengan memperhatikan kualitas pada daging ikan baik melalui kualitas dalam pada kandungan gizi daging ikan maupun kualitas luar pada pengamatan luar ikan. Kualitas kandungan gizi pada ikan yang diamati meliputi kandungan protein, lemak, vitamin, mineral, dan lain-lain. Sedangkan kualitas permukaan luar pada ikan diamati secara visual atau dapat dilihat dengan mata telanjang meliputi warna, aroma, tekstur, dan lain-lain. Oleh karena itu, untuk mengetahui adanya kualitas pada ikan secara lebih detail, dapat digunakan alat yang dikenal dengan ozon generator.

Ozon generator merupakan alat yang digunakan untuk mengetahui adanya kualitas pada bahan sampel termasuk bahan sampel penelitian khususnya pada sampel ikan air tawar. Fungsi dari alat ini adalah selain untuk sterilisasi pada bahan, alat ini juga berfungsi sebagai desifektan untuk 
membunuh mikroorganisme pada bahan sampel. Oleh karena itu, pada penelitian yang akan dilakukan adalah untuk mengetahui pengaruh penggunaan air ozon (ozone water) pada kualitas daging ikan dan bahan sampel yang dipakai adalah ikan bersisik, yaitu: ikan nila (Oreochromis niloticus).

\section{METODE PENELITIAN}

Penelitian dilaksanakan di Laboratorium Biofisika, Departemen Fisika, Fakultas Sains dan Teknologi Universitas Airlangga untuk melakukan ozonisasi serta menguji mutu kualitas (organoleptik) pada ikan nila (Oreochromis niloticus).

\section{Perlakuan Sampel}

Sampel yang digunakan dalam penelitian ini adalah ikan nila hidup (Oreochromis niloticus) yang diperoleh dari tempat budidaya ikan nila di Tanggulangin, Kota Sidoarjo dan sampel yang dibutuhkan sebanyak 48 ekor ikan. Penelitian ini dilakukan dengan Rancangan Acak Lengkap (RAL) yang melibatkan 2 kelompok, yaitu kelompok kontrol dan perlakuan. Kelompok perlakuan dibedakan menjadi 4 sampel dan dipapar dengan ozon yang telah diberi dengan air ozonisasi pada wadah (bak plastik) dengan waktu alir yang berbeda-beda, yaitu 0 menit $(0 \mathrm{~s}$ waktu paparan), 9 menit (540 s waktu paparan), 6 menit (360 s waktu paparan), dan 3 menit (180 s waktu paparan) dengan masing-masing konsentrasi ozon 0,0609 mg/L, 0,0406 mg/L, dan 0,0203 mg/L. Penelitian dilakukan dengan 3 kali perulangan. Pada pemaparan ozon melalui air dapat dilakukan dengan mengaliri air dengan mengunakan ozon sesuai waktu alir yang dibutuhkan. Menurut pernyataan (Widyani, 2008) mengatakan bahwa waktu perendaman dan pencucian terutama ikan dilakukan selama 15 menit.

\section{Pemaparan Ozon pada Ikan}

Pemaparan ozon pada ikan dilakukan untuk mengetahui bahwa pemaparan ozon dapat menghambat pembusukan pada ikan nila. Pemaparan ozon dapat dilakukan dengan berbagai variasi waktu alir yaitu 0 menit, 9 menit, 6 menit, dan 3 menit serta konsentrasi ozon $0,0609 \mathrm{mg} / \mathrm{L}$, $0,0406 \mathrm{mg} / \mathrm{L}$, dan $0,0203 \mathrm{mg} / \mathrm{L}$ pada kelompok perlakuan sedangkan pada kelompok kontrol tidak dipapar ozon.
Pemaparan ozon melalui air dapat dilakukan dengan membersihkan sisik ikan terlebih dahulu dan diletakkan pada wadah (bak plastik) kosong. Kemudian, menyalakan ozon generator yang sudah terhubung dengan selang pada wadah (bak plastik) yang berisi air sesuai waktu alir yang diinginkan. Setelah itu, merendam ikan nila selama 15 menit dan dimasukkan ikan nila (Oreochromis niloticus) ke dalam plastik klip dan diberi label serta disimpan pada suhu ruang. Selanjutnya, ikan nila (Oreochromis niloticus) dilakukan uji organoleptik setiap 12 jam sekali selama 48 jam. Selanjutnya, dilakukan pengambilan foto untuk bukti hasil pengamatan ikan nila. Berikutnya, dilakukan pengambilan daging ikan dan difillet daging ikan dan dimasukkan ke dalam plastik klip yang sudah diberi label sebelumnya. Dan disimpan fillet daging ikan dibawah es batu pada box styrofoam sekitar $5^{\circ} \mathrm{C}$ sedangkan ikan tanpa difillet diletakkan diatas es batu.

Pada kelompok kontrol, tidak dialiri ozon dan dilakukan perendaman pada ikan sama seperti perendaman ikan dengan menggunakan air berozon selama 15 menit. Kemudian dimasukkan ikan nila setelah perendaman ke dalam plastik klip dan disimpan ikan nila dibawah es batu. Setelah itu, ikan nila (Oreochromis niloticus) dilakukan uji organoleptik setiap 12 jam sekali selama 48 jam. Berikutnya, dilakukan pengambilan daging ikan dan difillet daging ikan dan dimasukkan ke dalam plastik klip yang sudah diberi label sebelumnya. Dan disimpan fillet daging ikan dibawah es batu pada box styrofoam sekitar $5^{\circ} \mathrm{C}$ sedangkan ikan tanpa difillet diletakkan diatas es batu.

\section{Pengujian Organoleptik pada Ikan}

Pengujian Organoleptik merupakan cara pengujian mutu ikan menggunakan indera manusia sebagai alat utama dalam menilai mutu ikan hidup berdasarkan SNI 01-2346-2006. Dalam penelitian yang akan diteliti meliputi kecerahan/warna, bau, dan tekstur. Metode pengujian yang dipakai dalam standar ini adalah uji scoring test, dengan menggunakan score sheet organoleptik ikan segar dengan kriteria angka 1 (satu) sebagai nilai terendah dan angka 9 (sembilan) untuk nilai tertinggi. 
Jurnal Biosains Pascasarjana Vol. 23 (2021) pp

(C) (2021) Sekolah Pascasarjana Universitas Airlangga, Indonesia

\section{Analisis Data}

Analisis data pada penelitian adalah dengan menggunakan pengujian organoleptik (penampakan luar) berupa uji scoring test, dengan menggunakan score sheet organoleptik ikan segar. Untuk uji organoleptik pada ikan nila berupa kenampakan mata, insang, lendir permukaan badan, daging, bau, dan tekstur pada daging ikan.

\section{HASIL DAN PEMBAHASAN}

\section{Pemaparan Ozon Melalui Air pada Ikan Nila}

(Oreochromis, niloticus)

Setelah dilakukan pemaparan ozon melalui air pada ikan nila (Oreochromis niloticus) diperoleh data berupa hasil uji scoring test pada uji organoleptik pada ikan dimana uji ini mencakup 6 spesifikasi pada ikan segar, yaitu perubahan pada mata, insang, lendir pada badan, daging, bau, dan tekstur Perubahan ikan nila dengan pemaparan ozon melalui air pada sampel kontrol dan sampel perlakuan dapat ditunjukkan pada gambar 1 dibawah ini:

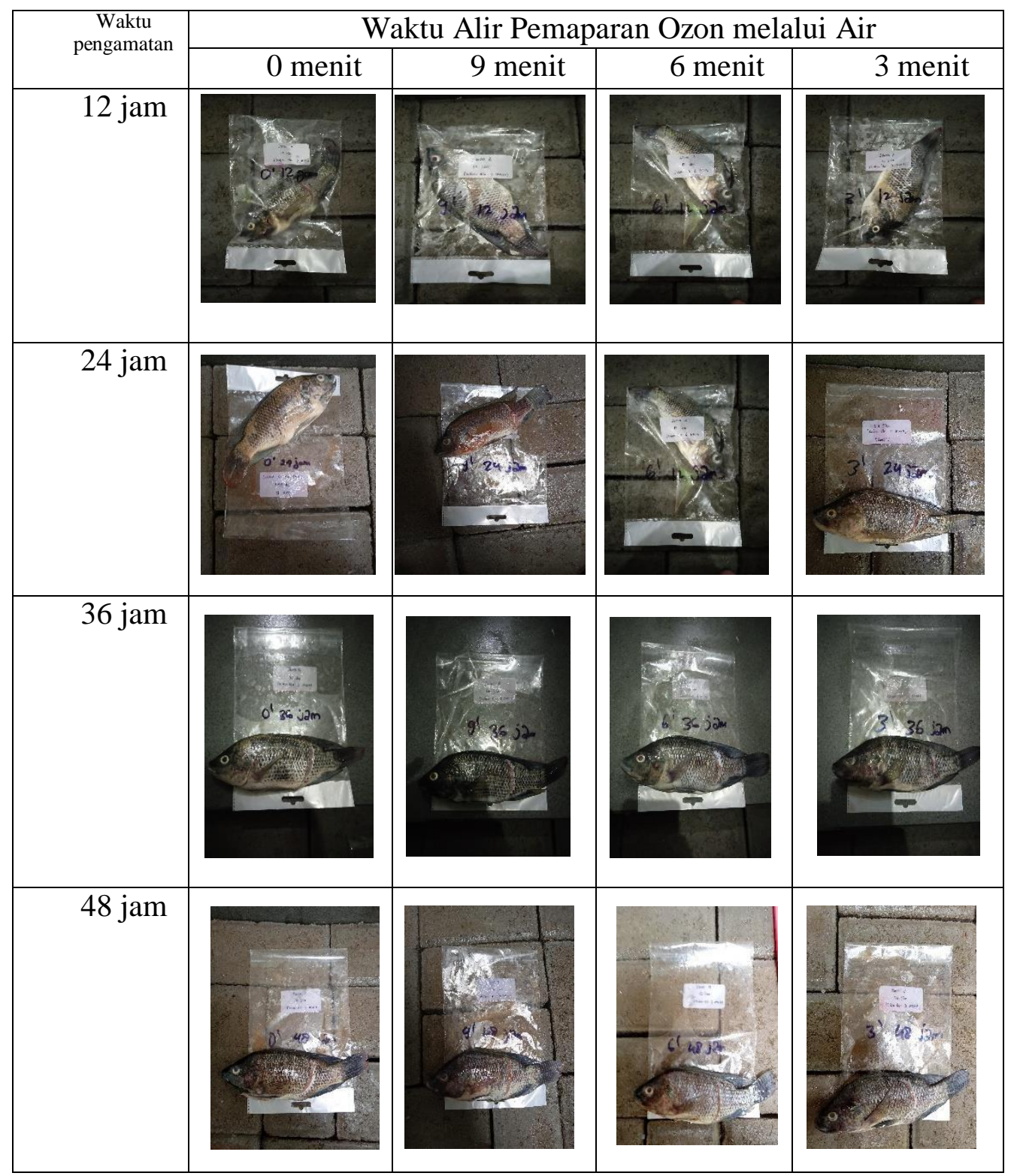

Gambar 1. Perubahan ikan nila dengan pemaparan ozon melalui air pada sampel kontrol dan sampel perlakuan

Berdasarkan Gambar 1, pemaparan ozon JBP Vol. 23, No.01, Juni 2021 - Yunus Susilo melalui air pada ikan nila (Oreochromis 
niloticus) dihasilkan data berupa uji organoleptik dalam bentuk uji scoring test pada ikan segar. Berdasarkan uji organoleptik pada ikan nila, pemaparan ozon melalui air dapat menjadikan ikan nila tersebut tidak cepat mengalami kerusakan.

Perlakuan pada pemaparan ozon melalui air mampu menjaga kualitas kesegaran pada ikan nila (Oreochromis niloticus) lebih baik dibandingkan dengan perlakukan kontrol pada ikan nila (Oreochromis niloticus). Pada perlakuan sampel ikan, waktu alir yang paling optimum dalam menjaga kualitas kesegaran ikan nila (Oreochromis niloticus) adalah waktu alir 3 menit dalam waktu penyimpanan selama 12 jam. Hal ini ditandai dengan penampakan mata cerah, dan kornea jernih, insang kurang cemerlang tetapi tanpa lendir, lendir jernih cerah mengkilat, bau sangat segar, dan teksturnya agak padat dan elastis jika ditekan daging dari tulang belakang. Sedangkan pada perubahan pada mata, insang, lendir permukaan badan, daging, bau, dan tekstur terjadi pada waktu alir 3 menit dalam waktu penyimpanan 36 jam yang ditandai dengan perubahan bola mata agak cekung, pupil mata berwarna keabuabuan, dan kornea agak keruh, insang berwarna merah kusam dan sedikit lendir, lendir pada badan ikan mulai keruh, berwarna putih agak kusam, dan kurang transparan, dan sayatan daging pada ikan mulai pudar, terdapat banyak pemerahan di sepanjang tulang belakang, dan dinding mulai agak lunak.

Pada perlakuan kontrol pemaparan ozon melalui air pada ikan nila (Oreochromis niloticus), waktu alir yang paling optimum (optimal) dalam menjaga kualitas kesegaran ikan nila (Oreochromis niloticus) terjadi pada waktu penyimpanan 12 jam yang ditandai dengan kualitas bola mata menonjol, jernih, dan cerah, kualitas warna insang kurang cemerlang dan tanpa lendir, lapisan lendir permukaan badan jernih, cerah, dan belum terjadi perubahan warna, kualitas dagingnya sangat cemerlang tidak ada pemerahan sepanjang tulang belakang serta dinding perut ikan masih utuh, bau pada kualitas bersifat netral, dan teksturnya agak padat dan elastis apabila ditekan dagingnya dari tulang belakang. Sedangkan perubahan kontrol yang terjadi pada perubahan mata, insang, lendir, daging, bau dan tekstur terdapat pada waktu penyimpanan selama 24 jam yang ditandai dengan perubahan bola mata agak cekung, pupil berubah warna menjadi putih keabu-abuan, dan kornea agak keruh, perubahan insang menjadi agak kusam dan sedikit lendir, permukaan lendir ikan mulai agak keruh warna agak putih, dan kurang transparan, aroma pada ikan mulai tercium amoniak dan sedikit bau asam.

\section{Pembahasan}

Pada penelitian ini dihasilkan dari generator ozon dengan metode lucutan plasma terhalang dielektrik. Menurut (Istiqomah, dkk, 2017) mengatakan bahwa lucutan plasma terhalang dielektrik terbentuk pada celah diantara 2 elektroda, yaitu elektroda dalam sebagai elektroda aktif dan elektroda luar sebagai elektroda pasif. Diantara kedua elektroda terdapat bahan isolator sebagai penghalang (barrier). Apabila kedua elektroda tersebut diberi tegangan listrik, maka akan menghasilkan tegangan listrik yang tidak homogen karena adanya tegangan listrik yang menyebabkan elektron dipercepat menuju anoda dan partikel bermuatan positif akan dipercepat menuju katoda. Molekul oksigen $\left(\mathrm{O}_{2}\right)$ yang dialirkan diantara 2 celah elektroda akan bertumbukkan dengan elektron sehingga yang dihasilkan dalam bentuk atom oksigen $\left(\mathrm{O}_{2}\right)$ akan menumbuk dengan molekul oksigen $\left(\mathrm{O}_{2}\right)$ lain akan menghasilkan molekul ozon $\left(\mathrm{O}_{3}\right)$.

Peningkatan konsentrasi ozon dapat dipengaruhi oleh besarnya tegangan yang diberikan. Besar tegangan masukan pada alat ozon generator sebesar 110 volt. Menurut (Nur, et. al, 2009) mengatakan bahwa tegangan pada konsentrasi ozon tersebut meningkat seiring dengan meningkatnya waktu alir ozon. Hal ini terjadi karena filamen-filamen pada arus yang melewati generator ozon bersifat kontinyu dan celah sempit yang dilewati oleh molekul oksigen $\left(\mathrm{O}_{2}\right)$ selalu bergerak yang berdasarkan pada waktu alir ozonisasi. Semakin banyak plasma yang terbentuk akan menyebabkan konsentrasi ozon tersebut semakin besar. Secara fisis, konsentrasi ozon dapat dinyatakan dengan jumlah ozon per satuan volume ozon yang dinyatakan dengan satuan $\mathrm{mg} / \mathrm{L}$.

Berdasarkan penelitian yang telah dilakukan 
Jurnal Biosains Pascasarjana Vol. 23 (2021) pp

(C) (2021) Sekolah Pascasarjana Universitas Airlangga, Indonesia

terhadap sampel ikan nila (Oreochromis

niloticus) diketahui bahwa pemaparan ozon

terhadap air dapat menghambat waktu kerusakan pada sampel ikan nila (Oreochromis niloticus) dibandingkan dengan pemaparan ozon melalui udara yang ditandai dengan pengujian organoleptik (pengujian kenampakan luar).

Ikan nila (Oreochromis niloticus) yang dipapar ozon melalui air mampu menghambat kualitas ikan selama penyimpanan. Hal ini menunjukkan bahwa pemaparan ozon pada perlakuan sampel ikan nila (Oreochromis niloticus) mampu bertahan lebih lama daripada perlakuan kontrol. Mekanisme pemaparan ozon terhadap ikan nila (Oreochromis niloticus) dapat dilihat pada Gambar 2.

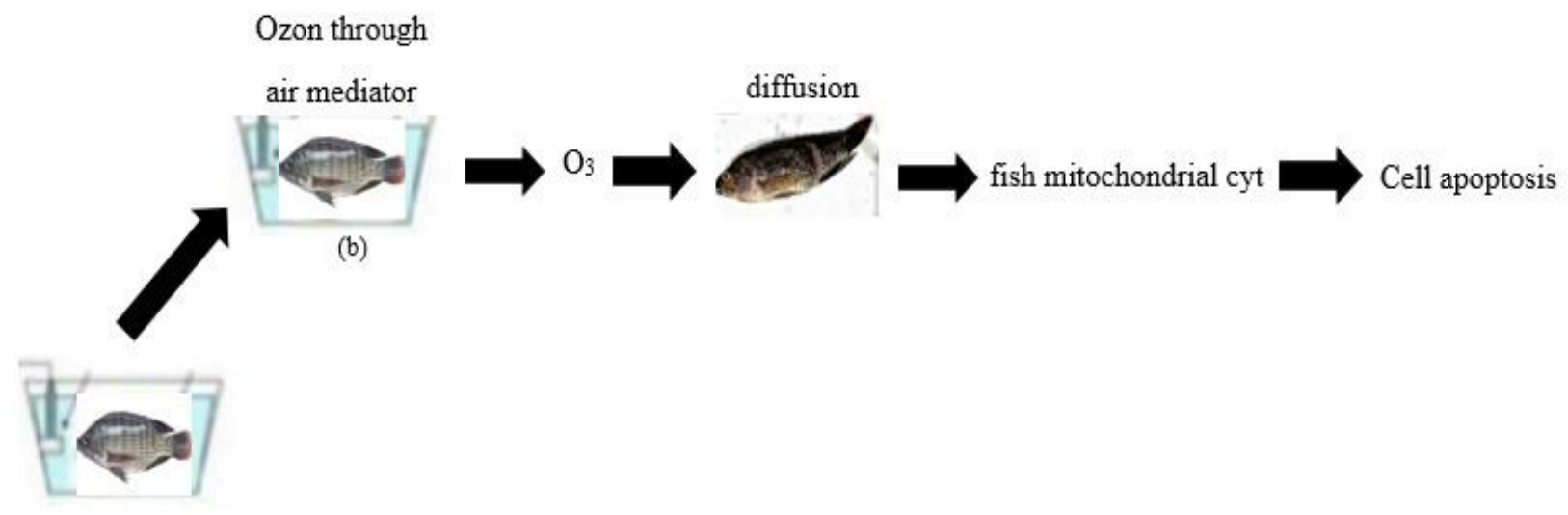

(a)

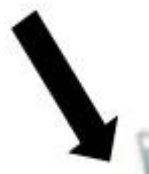

Ozon through water mediator
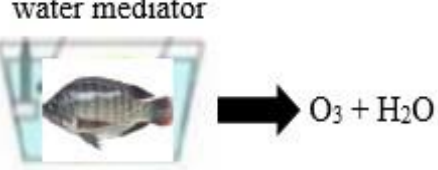

diffusion

(c)

Gambar 2. Mekanisme pemaparan ozon terhadap ikan nila, yaitu (a) sampel yang dipapar ozon dengan dua teknik paparan, (b) ozon berdifusi ke jaringan ikan nila yang dipapar ozon melalui udara lewat daging ikan dan menyebabkan sel apoptosis atau rusak. (c) ozon berdifusi ke jaringan ikan nila yang dipapar ozon melalui air lewat permukaan daging ikan dan menghambat respirasi sel. 
Paparan ozon melalui udara terhadap ikan nila (Oreochromis niloticus) memberikan perubahan pada uji organoleptik lebih cepat dibandingkan dengan perlakuan kontrol sehingga paparan ozon melalui udara dapat mempercepat kerusakan sel pada ikan nila (Oreochromis niloticus). Hal ini disebabkan karena oksigen yang tidak stabil pada ozon akan berdifusi ke jaringan pada ikan nila (Oreochromis niloticus) sehingga elektron pada jaringan akan tereksitasi ke tingkat energi yang lebih tinggi. Elektron yang tereksitasi akan bereaksi dengan sistem biologis dengan melakukan transfer proton atau elektron membentuk anion dan kation radikal. Ion radikal berinteraksi dengan oksigen menghasilkan oksigen reaktif yang dikenal dengan sebutan Reactive Oxygen Spesies (ROS). Reaksi transport elektron menghasilkan anion superoksida $\left(\mathrm{O}_{2}{ }^{-}\right)$. Anion superoksida $\left(\mathrm{O}_{2}{ }^{-}\right.$ ) bereaksi dengan sistem biologis akan membentuk radikal hidroksil $(\bullet \mathrm{OH})$. Radikal hidroksil $(\cdot \mathrm{OH})$ berdifusi ke dalam sel ikan nila (Oreochromis niloticus) sehingga dapat menimbulkan peningkatan permeabilitas membran mitokondria yang menyebabkan sitokrom c dari mitokondria dilepaskan ke dalam sitoplasma sehingga sel tersebut mengalami apoptosis.

Paparan ozon melalui air pada ikan nila (Oreochromis niloticus) dapat mempertahankan kualitas kesegaran pada ikan hingga hari ke 16 dapat dilihat dari segi aspek organoleptiknya sedangkan sampel pada perlakuan kontrol hanya bertahan selama 12 hari (Haifan, 2017). Sehingga paparan ozon melalui air dapat menghambat kerusakan pada ikan nila (Oreochromis niloticus). Hal ini terjadi karena ozon akan mengoksidasi ion-ion yang terdapat di dalam air sehingga ozon mengalami dekomposisi ozon. Dekomposisi ozon terjadi ketika ozon bereaksi dengan ion $\mathrm{OH}^{-}$pada air (Calvosa et. al., 1991). Ion hidroksida $\left(\mathrm{OH}^{-}\right)$pada dekomposisi ozon berperan sebagai inisiator yang dapat mempercepat pembentukan $\mathrm{OH}$ radikal yang bersifat tidak selektif, sehingga ozon tersebut akan dioksidasi oleh $\mathrm{OH}$ radikal (Nurita, 2013). Hasil dekomposisi ozon berupa ion radikal hidroksil $(\bullet \mathrm{OH})$. Ion radikal hidroksil $(\bullet \mathrm{OH})$ yaitu ion radikal bebas yang bersifat merusak. Pembentukan radikal hidroksil $(\bullet \mathrm{OH})$ di dalam air dipengaruhi oleh senyawa-senyawa yang bertindak sebagai inisitor, inhibilitor, dan promotor.

Senyawa yang bertindak sebagai inisiator ialah hidrogen peroksida $\left(\mathrm{H}_{2} \mathrm{O}_{2}\right)$. Hidroksi peroksida $\left(\mathrm{H}_{2} \mathrm{O}_{2}\right)$ akan bereaksi dengan ozon ketika menghasilkan ion radikal superoksida $\left(\mathrm{O}_{2}^{-}\right)$. Menurut (Monica, 2010) mengatakan bahwa ion radikal superoksida merupakan kunci terbentuknya radikal bebas yang ditandai dengan terbentuknya reaksi cepat dengan ozon pada ion radikal superoksida sehingga dapat menghasilkan ion radikal ozonide. Ion radikal ozonide akan bereaksi dengan ozon yang menghasilkan radikal radikal hidroksil $(\cdot \mathrm{OH})$. Senyawa yang bertindak sebagai inisiator adalah hidrogen peroksida $\left(\mathrm{H}_{2} \mathrm{O}_{2}\right)$. Hidrogen peroksida $\left(\mathrm{H}_{2} \mathrm{O}_{2}\right)$ bereaksi dengan radikal hidroksil $(\cdot \mathrm{OH})$ dan mampu mempropagasi rantai pada radikal untuk menghasilkan ion radikal superoksida $\left(\mathrm{O}_{2}{ }^{-}\right)$. Senyawa yang bertindak sebagai inhibitor yaitu ion karbonat yang berperan sebagai menghentikan rantai radikal. Menurut (Krisnawati, et. al. 2014), mengatakan bahwa ion karbonat tidak akan bereaksi dengan radikal hidroksil $(\bullet \mathrm{OH})$. Sehingga radikal tersebut tidak akan bereaksi dengan ozon. Hal inilah yang dapat menghambat pembentukan ion radikal superoksida $\left(\mathrm{O}_{2}^{-}\right)$sehingga dapat menghentikan rantai radikal.

Ion radikal hidroksil $(\bullet \mathrm{OH})$ yang dihasilkan oleh air berozon akan 
berdifusi ke dalam sel pada ikan nila (Oreochromis niloticus) dan menyebabkan enzim pada sitoplasma ikan tersebut non aktif (tidak aktif) dan enzim yang tidak aktif akan menyebabkan respirasinya terhambat sehingga dapat menghasilkan air. Terhambatnya proses respirasi pada ikan nila (Oreochromis niloticus) dapat mampu mempertahankan kualitas mutu kandungan air pada ikan nila (Oreochromis niloticus).

Enzim yang terkandung di dalam tubuh ikan akan merombak bagian tubuh ikan dan mengakibatkan perubahan pada ikan nila (Oreochromis niloticus), antara lain perubahan rasa (flavour), bau, bentuk (kenampakan), dan tekstur serta aktivitas kimiawi. Aktivitas kimiawi adalah suatu oksidasi lemak daging oleh oksigen $\left(\mathrm{O}_{2}\right)$. Oksigen yang terkandung di udara dapat mengoksidasi lemak daging yang berlemak sehingga aroma pada ikan menyebabkan bau anyir (bau amis). Perubahan ini disebabkan oleh bakteri yang dipicu oleh terjadinya kerusakan komponen pada ikan akibat aktivitas enzim dan aktivitas kimia. Aktivitas kimia inilah yang menghasilkan komponen-komponen enzim yang lebih kompleks (Nur, et., al., 2014).

Proses hilangnya air dapat disebabkan karena proses penguapan atau evaporasi. Hal ini terjadi karena pengaruh suhu atau temperatur (T). Ketika ikan nila (Oreochromis niloticus) ditempatkan pada suhu yang rendah, akan terjadinya proses secara fisika berupa Hukum termodinamika ke-0 yaitu proses kesetimbangan termal. Kesetimbangan termal yaitu suatu keadaan atau proses yang dimana aliran energi tersebut dapat menyamakan temperaturnya. Apabila ikan nila (Oreochromis niloticus) tersebut ditempatkan pada suhu rendah, misalnya pada kulkas atau lemari pendingin, maka akan terjadi aliran energi yang terdapat pada ikan nila (Oreochromis niloticus) dari dalam menuju lingkungan luar (eksternal).
Aliran energi yang dapat mempercepat peristiwa evaporasi atau penguapan. Evaporasi dapat mempercepat hilangnya kandungan air pada ikan nila (Oreochromis niloticus) sehingga dapat menyebabkan ikan nila (Oreochromis niloticus) lebih cepat busuk ketika ditempatkan pada suhu yang lebih rendah.

Ikan nila (Oreochromis niloticus) akan tetap melakukan respirasi dan dapat menghasilkan fungsionalitas pada protein myofibriliar dari ikan nila (Oreochromis niloticus) sehingga dapat meningkatkan kelarutan garam, aktivitas kimiawi $\mathrm{Ca}_{2}+$-ATPase, kandungan karbonil, dan kandungan surfhidril (Susanti et. al., 2019). Ion radikal hidroksil $(\mathrm{OH})$ dalam air berozon akan melakukan interaksi dengan mikroorganisme pada ikan nila (Oreochromis niloticus). Ozon akan masuk ke dalam sel mikroba kemudian sel mikroba tersebut dapat mengubah permeabilitas dari mikroba tersebut menjadi lisis atau pecah sehingga mikroorganisme pada ikan nila (Oreochromis niloticus) akan mati. Hal ini dapat melindungi ikan nila (Oreochromis niloticus) dari mikroorganisme penyebab kebusukan.

Sensitivitas pada mikroorganisme terhadap ozon dapat dipengaruhi oleh berbagai faktor-faktor seperti strain mikroorganisme, keadaan fisiologis sel, tingkat pertumbuhan, keadaan $\mathrm{pH}$ medium, suhu, dan kelembapan (Zorlugenc et al., 2008). Akan tetapi, kelebihan oksigen pada hasil penguraian ozon yang tersisa merupakan menu utama bagi pertumbuhan mikroorganisme-mikroorganisme yang belum mati sehingga mikroba pada tekstur ikan menjadi lunak. Pelunakan pada ikan disebabkan oleh perubahan yang terjadi di dinding sel pada tubuh ikan. Selain terjadi pelunakan, ikan nila (Oreochromis niloticus) juga mengalami perubahan warna, bau dan tekstur selama dilakukan pengamatan pada kualitas 
mutu ikan nila (Oreochromis niloticus).

Penggunaan ozon pada ikan nila (Oreochromis niloticus) dapat memperpanjang daya waktu penyimpanan pada ikan. Hal ini dikarenakan penggunaan ozon pada ikan tidak menghasilkan residu yang bersifat beracun dan dapat terhindar dari kontaminasi pada ikan segar yang baru saja ditangkap sehingga pemakaian ozon dapat terjamin keamanannya. Hasil dari penggunaan ozon pada ikan dapat dilihat dari aspek sensori pada ikan nila (Oreochromis niloticus) pada penggunaan ozon lebih baik dibandingkan dengan penyimpanan ikan dengan menggunakan es batu. Untuk meningkatkan mutu kualitas ikan nila (Oreochromis niloticus) selama dilakukan penyimpanan pada penggunaan ozon, maka dilakukan pengujian organoleptik (pengujian kualitas luar dan kenampakan) pada ikan nila (Oreochromis niloticus) dengan tujuan untuk mengetahui waktu penyimpanan setelah diberi ozon dengan waktu penyimpanan tanpa diberi ozon (Kontrol).

Dalam melakukan pengujian organoleptik (penampakan luar) pada ikan nila (Oreochromis niloticus) akan dilakukan pengujian setiap 12 jam sekali selama 48 jam dapat digunakan dengan $u j i$ scoring test dengan tujuan untuk menilai keadaan pada penampakan mata, insang, lendir permukaan badan, daging, bau, dan tekstur dalam bentuk score. Nilai score tertinggi pada pengujian organoleptik terdapat pada score 9, sedangkan nilai score terendah terdapat pada score 1. Berdasarkan penelitian pengujian organoleptik ikan nila (Oreochromis niloticus) dapat ditunjukkan bahwa nilai pengujian organoleptik ikan nila (Oreochromis niloticus) selama disimpan selama 12 jam sekali baik pada perlakuan kontrol maupun perlakuan yang dialiri ozon terjadi perubahan pada spesifikasi ikan pada mata, insang, lendir permukaan badan, daging, bau, dan tekstur dimana nilai tertinggi menunjukkan bahwa ikan tersebut dalam keadaan segar, sedangkan nilai terendah menunjukkan bahwa ikan tersebut mengalami pembusukan. Hal ini dapat menjadi faktor-faktor yang mempengaruhi kualitas dalam waktu penyimpanan ikan baik perlakuan kontrol maupun perlakuan diberi ozon. Pada perlakuan kontrol hanya bertahan hingga 12 jam sedangkan pada waktu penyimpanan ke 24 jam, 36 jam, dan 48 jam mengalami perubahan yang secara spesifik baik kualitas pada mata, insang, lendir pada ikan, daging, bau, dan tekstur. Pada perlakuan yang diberi ozon dapat bertahan lebih lama dan mengalami perubahan pada jam ke 36 yang berdasarkan pada waktu alir yang digunakan (9 menit, 6 menit, dan 3 menit) dan tidak seperti pada perlakuan kontrol tanpa diberi ozon dimana penyimpanannya sangat singkat karena terjadi perubahan pada kualitas bentuk spesifikasi pada ikan sehingga pada pengujian ini perlu dilakukan secara teliti dan cermat baik perlakuan kontrol maupun perlakuan diberi ozon.

Perlakuan pada ozon dapat menghasilkan kualitas mutu pada ikan secara aspek sensori serta dapat mencegah timbulnya miroorganisme atau jamur dan proses pembusukan pada ikan sehingga dapat ditinjau dari karakteristik konsentrasi molekul ozon berupa pengaruh enzim intraseluler, asam nukleat, dan komponen sel lainnya dari mikroorganisme tersebut. Oleh karena itu, pengujian organoleptik inilah yang dapat memperpanjang kapasitas penyimpanan ikan dengan menggunakan teknologi ozon (Yuliani, et., al., 2018).

\section{KESIMPULAN DAN SARAN}

Paparan ozon melalui mediator udara dapat mempercepat kerusakan organoleptik ikan nila (Oreochromis niloticus) sedangkan paparan ozon melalui mediator air dapat menghambat kerusakan organoleptik ikan nila 
(Oreochromis niloticus).

Paparan ozon melalui mediator air dapat menghambat waktu kerusakan mutu ikan nila (Oreochromis niloticus) 36 jam lebih lambat dibandingkan dengan perlakuan kontrol ikan nila (Oreochromis niloticus) serta perlakuan yang paling efektif dalam menghambat kerusakan kualitas mutu ikan nila (Oreochromis niloticus) ialah pemaparan ozon melalui air dengan konsentrasi ozon $0,0203 \mathrm{mg} / \mathrm{L}$ ditinjau dari organoleptiknya serta spesifikasi pada ikan yang paling efektif dalam menghambat kerusakan adalah terdapat pada penampakan lendir permukaan badan dan bau.

Pada penelitian kedepannya perlu dilakukan banyak orang, baik panelis yang menangani pengujian organoleptik maupun mahasiswa perikanan dan kelautan. Penelitian organoleptik dengan menggunakan panelis sebanyak 15 orang sedangkan mahasiswa perikanan dan kelautan diperlukan sebanyak 30 orang dan kerjasama antara mahasiswa fisika dengan mahasiswa perikanan dan kelautan guna melakukan penelitian pengujian organoleptik pada ikan serta dilakukan pengujian kandungan yang diperoleh dari hasil ozonisasi pada ikan setelah dilakukan pengujian organoleptik pada ikan dengan menggunakan teknologi ozon.

\section{DAFTAR PUSTAKA}

Astuti SD, Pratiwi WI, Tanassatha SA, Alamsyah KA, Susilo Y, Khasanah M,

2021. Effect of Ozone-induced Diode Laser of Photodynamic Inactivation on Pseudomonas aeruginosa, Mal $\mathrm{J}$ Med Health Sci 17(SUPP2): 27-32

Astuti SD., Purnobasuki H., Khasanah M., Khoiriyatul S., Nurul Fitriyah N., Arifianto D. and Ama F., 2020. The influence of ozone exposure on organoleptic and chlorophyll levels of curly lettuce (Lactuca sativa L.). Env. Eco \& Cons. 26 (November Suppl. Issue) : 2020; pp. (S300-S308)
Astuti S.D., Drantantiyas N.D.G., Putra A.P., Puspita P.S., Syahrom A., Suhariningsih, Photodynamic effectiveness of laser diode combined with ozone to reduce Staphylococcus aureus biofilm with exogenous chlorophyll of Dracaena angustifolia leaves, Biomedical Photonic, 2019, 8(2): 4-13

Calvosa, L., A. Monteverdi., B. Rindone., G. Riva., 1991. Ozone Oxidation of Compounds Resistant to Biological Degradation. Journal of Technology. 25, 985 - 993.

Gustini, Khotimah, S., \& Yanti, A. H. 2014. Kualitas Ikan Kembung (Rastrelliger kanagurta) Setelah Perendaman Dalam Kitosan ditinjau dari Aspek Mikrobiologi dan Organoleptik. Jurnal Protobiont, 3(2), $100-105$.

Haifan, Mohamad. 2017. Review Kajian Aplikasi Teknologi Ozon untuk Penanganan Buah, Sayuran dan Hasil Perikanan. Jurnal IPTEK, 1(1): 15 - 21.

Irawan. 1997. Pengawetan dan Pengolahan Ikan. Yogyakarta: Penerbit Kanisius.

Istiqomah, Nur, Muhammad, Arianto, Fajar. 2017. Karakterisasi Reaktor Plasma Lucutan Berpenghalang Dielektrik Berkonfigurasi Elektroda Spiral-Silinder dengan Sumber Udara Bebas. Youngster Physics Journal, 6(3), 235 - 241.

Krisnawati, Amalia., M. Rangga Sururi., Siti Ainun., 2014. Pengaruh Karakteristik Lindi terhadap Ozonisasi Konventional dan Advanced Oxidation Processes (AOP). Jurnal Rekayasa Lingkungan. 2, 1 $-9$.

Monica, Rumia S. 2010. Studi Perpindahan Massa dan Dekomposisi Ozon pada Proses Oksidasi Lanjut Berbasis Ozon. Skripsi. Tidak Diterbitkan. Fakultas Teknik. Universitas Indonesia: Depok.

Nur, Muhammad, dkk. 2009. Ozone Generator by Using Dielectric Barrier Discharge Plasma Technology With Spiral-Cylinder Configuration: Comparison Between Oxygen and Air As Sources. Berkala Fisika, 12(2), 69 - 76.

Nur, Muhammad, dkk. 2014. Development of Ozone Technology Fish Storage Systems for Improving Quality Fish Production. International Symposium on Technology Management and Emerging Technologies (ISTMET 2014), 167 - 172. 
Nurita Sari, Nanda, Sururi, Rangga, Pharmawati, Kancitra. 2013. Efek Perlakuan pH pada Ozonisasi. Reka Lingkungan Jurnal Institut Teknologi Nasional, 1(1): 1 - 12.

Prasetyo, A., Nur, M., Muhlisin, Z., \& Putro, P. 2015. Pengaruh Ozon yang Dibangkitkan Menggunakan Reaktor Dielectric Barrier Discharge Plasma Terhadap Konsentrasi Oksigen Terlarut, Kesadahan, dan $\mathrm{pH}$ pada Air Murni. Youngsters Physics Journal, 4(3), $237-242$.

Purwadi, A., Usada, W., Suryadi, Isyuniarto, dan Sukmajaya, S. 2003. Rancang Bangun Ozonizer Ganda dan Manfaatnya. 21 29.

Putri S. Puspita, Astuti SD, Aulia M.T. Nasution, Anak A.S. Pradhana and Amiliyatul Mawaddah, Photodynamic Therapy with Ozone aids to Staphylococcus aureus Biofilm Reduction, Indian Vet. Journal, 2020, 97 (02) : 24 - 26

Susanti, Epa, dkk. 2019. Analisis Kekuatan Gel Surimi Ikan Lele (Clarias gariepinus) Hasil Ozonasi Selama Pnyimpanan pada Suhu $4 \pm 10$. Pasundan Food Technology Journal, 6(2), 91 - 94.

Wibowo, I. R., Darmanto, Y., \& Anggo, A. D. 2014. Pengaruh Cara Kematian dan Tahapan Penurunan Kesegaran Ikan Terhadap Kualitas Pasta Ikan Nila (Oreochromis niloticus). Jurnal Pengolahan Dan Bioteknologi Hasil Perikanan, 3(3), 95 - 103.

Widyani, Retno, dan Suciany, Tety. 2008. Prinsip Pengawetan Pangan. Cirebon: Penerbit Swagati Press.

Yuliani, Y., dkk. 2018. Ozone Immersion Treatment to Increase the Shelf Life of Tuna Fish, Milk Fish, and Shrimp in a Cold Storage System. IOP Conference Series: Materials Science and Engineering. Pp. 1-7.

Zorlugenç, Bülent., Feyza Kirog., `lu Zorlugenç., Serdar Öztekin I., Bülend Evliya., 2008. The influence of gaseous ozone and ozonated water on microbial flora and degradation of aflatoxin B1 in dried figs. Food and Chemical Texicology. 46, 3593-3597. 